
\title{
M.
}

\section{THE EFFECT OF LEADERSHIP AND SUPERVISION ON EMPLOYEE DISCIPLINE AT PT. PERKEBUNAN NUSANTARA III (PERSERO) KEBUN BANDAR SELAMAT}

\author{
Rahmad Bahagia ${ }^{1}$, Siti Sarah², Linzzy Pratami Putri ${ }^{3}$ \\ rahmadbahagia@umsu.ac.id \\ University of Muhammadiyah Sumatera Utara
}

\begin{abstract}
The results of this study have the aim of knowing the existence of "The Influence of Leadership and Supervision on Employee Discipline at PT. Perkebunan Nusantara III (Persero) Kebun Bandar Selamat". The approach taken in this study uses an associative approach. The population in this study were all employees at PT. Perkebunan Nusantara III (Persero) Kebun Bandar Selamat, totaling 264 people with a sample of 72 people using the slovin formula. The data analysis technique uses the Classical Assumption Test, Multiple Linear Regression, Hypothesis Testing (T Test, F Test), \& Coefficient of Determination. Data processing in this study using the SPSS 25.00 software program. The data collection technique used a questionnaire technique by producing a positive influence between Leadership on Employee Discipline which could state tcount ttable 4.7842 .972 significant 0.00 0.05. There is a positive influence on employee discipline at PT. Perkebunan Nusantara III (Persero) Kebun Bandar Selamat with tcount 4.784 1,401 ttable significantly.The conclusion of the research on the influence of leadership and supervision on employee discipline at PT. Perkebunan Nusantara III (Persero) Kebun Bandar Selamat states that there is a positive influence, which is based on the results of the Fcount test of 12,984 with a significant value of 0.000 and the value of Ftable 2.391, because Fcount Ftable then Ha rejected.
\end{abstract}

Keywords: Leadership, Supervision, Discipline

\section{BACKGROUND}

Facing today's competition, organizations/companies must have strong and effective resources. The resources needed to run the company cannot be seen as a unit that can stand alone but must be seen as a formidable unit and form a new and formidable synergy. In this case, the role of human resources is very decisive in the world of work (Jufrizen, 2017).

Summarizing resource management is the only resource that has sense, knowledge, skills, encouragement and abilities. All the potential of human resources is very influential on the organization's efforts to achieve a goal. No matter how advanced a technology, the development of information, and the availability of capital, if without human resources in the company it is difficult for him to achieve a goal. The influence of good discipline can reflect an attitude, appearance, behavior and actions that are in accordance with the regulations that have been made and compiled from the company, which are actually obeyed and implemented both written and unwritten. Discipline shows a condition or an attitude of respect that exists in employees towards company rules and regulations. Good employee discipline will accelerate company goals, while declining discipline will become a barrier and slow down the achievement of company goals (Kamal, 2015).

An orderly condition in which a person or group of people who join the company wishes to comply with and carry out the company's regulations, both written and unwritten. In work discipline, it is required the ability to live up to the rules, norms, laws and regulations that apply in the company and to ensure the maintenance of order and the smooth implementation of each task. There are several other factors in influencing work discipline, 
namely leadership. Leadership is a person's abilities and skills when serving as a leader in a company or world of work to be able to influence the behavior of others, especially their subordinates (Afandi \& Bahri, 2020).

Leadership is a set of characteristics used by leadership to influence subordinates so that organizational goals are achieved or it can also be said that leadership is a pattern of behavior and strategies that are preferred and often applied by a leader (Afandi \& Bahri, 2020). It can also be interpreted according to leadership is the process of directing and influencing activities that have to do with the work of group members (Hahagia et al., 2018). In the life of the company, the leadership has a very important role, especially in supervising the employees. All good activities ranging from planning, implementation, supervision to setting goals are determined by the leadership. Supervision is a systematic effort to apply performance standards to plans for designing information feedback systems, supervision is a systematic effort to set implementation standards with planning objectives, design information systems, compare real activities with predetermined standards. to take the necessary corrective actions to ensure that all resources are used as effectively and efficiently as possible to achieve organizational goals (Mockler, 2006).

Every company or organization requires supervision from superiors or leaders. Supervision is carried out by superiors as an attempt to compare whether what is being done is in accordance with a predetermined plan or strategy. In this case, supervision is the treatment of managers who strive so that work can be carried out in accordance with a predetermined plan. Something related to supervision is found in employees. Because there are still many employees who intentionally leave ready-to-harvest fruit on the tree and do not harvest it, so the fruit yields are lower than the company's estimates and targets. Here the supervision of leaders who lack firmness in the form of sanctions if employees violate and do not comply with the applicable rules at PT. Perkebunan Nusantara III (Persero) Kebun Bandar Selamat. Likewise with the leadership style at PT. Perkebunan Nusantara III (Persero) Kebun Bandar Congratulations for leaders who do not have firmness because if the leadership is not firm, it can lead to a lack of discipline that is not good in carrying out company goals, it is also seen in employees who take time off work and in their work are not complete in harvesting fruit palm oil that is not given any sanctions. There are several factors that trigger a lack of discipline, namely the undisciplined leadership of managers which causes employees to follow the attitude of their leaders (A. E. Nasution \& Lesmana, 2018).

Leadership and supervision factors are important factors for the company in achieving the goals that have been set. Therefore, managers must carry out effective work supervision, then automatically the discipline of their employees will be good so that employees can achieve optimal work performance in the form of work productivity. Employees at the oil palm harvester at the company PT. Perkebunan Nusantara III (Persero) Kebun Bandar Selamat tends to lack supervision from its superiors so that employee discipline is lacking. This situation if left unchecked will cause losses in the company. In the initial research that has been conducted by the author at PT. Perkebunan Nusantara III (Persero) Kebun Bandar Selamat is still experiencing low employee discipline so that there are still employees who often delay work, lack of leadership level in providing direction so that employee performance does not go well and precisely. 


\section{LITERATURE REVIEW}

Work Discipline

The definition of work discipline is an attitude of respect, obedience, and obedience to applicable regulations, both written and unwritten and being able to carry out them and willing to accept sanctions if they violate the duties and authorities that have been given to them (Arda, 2017). According to (Tyas \& Sunuharyo, 2018) Discipline is the willingness of someone who arises with his own awareness to follow the rules that apply in the organization. Discipline is an attitude of respect that exists in employees, which allows them to adapt voluntarily to comply with company rules and regulations.

According to (S. N. Nasution \& Pasaribu, 2020) work discipline is a tool used by managers to communicate with employees so that they are willing to change a behavior as well as an effort to increase awareness and willingness to obey all company regulations and applicable social norms (Tanjung, 2017). Work discipline can also be interpreted as an ideal situation in supporting the implementation of tasks according to the rules in order to support work optimization (Kamal, 2015). In various aspects of assessment, according to experts, it can be concluded that work discipline is work discipline is an attitude, behavior and action that is in accordance with the regulations of the company, both written and unwritten. applicable norms, laws and regulations so that they will consciously implement and obey them (Faustyna \& Jumani, 2017).

\section{Leadership}

An organization's success or failure can largely be determined by leadership. A noble expression which says that the leader is responsible for failure in the implementation of a job, is an expression that places the position of the leader in an organization or company in the most important position (Jufrizen, 2017). This expression can prove that a leader, whatever his form, wherever he is, will always have a burden to be responsible for his leadership (Rizal \& Radiman, 2019). This kind of leader works more than talks, and sets more good examples (Siagian \& Khair, 2018). According to (Hasni, Noviantoro, \& Septiani, 2020) Leadership is a social interaction in which a leader seeks to get the full support and participation of his employees in order to achieve organizational goals. Leadership as an ability that can influence a group towards achieving a vision or goal that has been set (Gede \& Priartini, 2018).

In a company leadership is a crucial factor, because the company needs a captain or driving force for its members who are expected to have a good impact on the company in a better direction at all times, one of which is the leadership style needed to achieve the company's vision or goals as the driving force for its subordinates to carry out their work (Gede \& Priartini, 2018). Based on several understandings that have been known from the experts above, it can be concluded that leadership is a process that can influence what is done by a person in managing his group members to achieve organizational or company goals (Afandi \& Bahri, 2020).

\section{Supervision}

Supervision in the operation of the company is very necessary to prevent various obstacles in the implementation of every organizational activity within the company or business entity, both government-owned and privately owned. The expected effect of the implementation of the supervisory function is to increase company performance and 
employee work performance (Jufrizen, 2016). In every action taken by the company there needs to be supervision, which will direct employees to be able to carry out work properly and in accordance with what has been determined. However, it is human nature that they always want to be free, without being bound or bound by any regulations (Kamal, 2015).

According to (Sari, Lie, \& Inrawan, 2015) supervision is a systematic effort to set implementation standards with planning objectives, designing systems information, comparing real activities with predetermined standards (I. M. Nasution, 2016). Supervision is choosing the right person for each job, creating interest in each person's work and teaching him how to do his job (Sari et al., 2015). Supervision can be interpreted as a process to determine what work has been carried out, evaluate it, and if necessary correct it with the intention that the implementation of the work is in accordance with the original plan (Rizal \& Radiman, 2019a).

Based on the supervision that has been explained according to the experts, it can be concluded that supervision is determining what has been carried out, meaning by evaluating work performance and if necessary to implement corrective actions so that the work results are in accordance with what has been expected.

\section{METHOD OF RESEARCH}

The research approach describes the form of research that underlies a research. A study may use one approach or several approaches at once. One of them can be seen with the aim, the research uses a quantitative approach, but if viewed from the approach, the research uses a quantitative causal approach.

\section{DATA ANALYSIS AND DISCUSSION Multiple Regression Linear}

Table 8. Multiple Regression Linear

\begin{tabular}{|c|c|c|c|c|c|c|}
\hline \multicolumn{7}{|c|}{ Coefficients $^{\mathbf{a}}$} \\
\hline & \multirow[b]{2}{*}{ Model } & \multicolumn{2}{|c|}{$\begin{array}{l}\text { Unstandardized } \\
\text { Coefficients }\end{array}$} & \multirow{2}{*}{$\begin{array}{c}\begin{array}{c}\text { Standardized } \\
\text { Coefficients }\end{array} \\
\text { Beta }\end{array}$} & \multirow[b]{2}{*}{$\mathrm{t}$} & \multirow[b]{2}{*}{ Sig. } \\
\hline & & $\mathrm{B}$ & Std. Error & & & \\
\hline \multirow[t]{3}{*}{1} & (Constant) & 7.104 & 2,391 & & 4,784 & 004 \\
\hline & Leadership & 426 & 097 & 492 & 2,972 & .000 \\
\hline & Supervision & 146 & 105 & 144 & 1,401 & .006 \\
\hline
\end{tabular}

a. Dependent Variable: Work Dicipline

Source: Data Processing Results (2021)

From the data above, the regression equations that can be loaded are:

$\mathrm{Y}=7,104+0,426 \mathrm{X} 1+0,146 \mathrm{X} 2$

The regression equation above can be explained as follows:

1. The value of 7,104 shows that the value if the value of the independent variable is considered constant, then the Work Dicipline is equal to 7,104. 


\section{ORFAI JOURNAL \\ Multidiciplinary Output Research For \\ Actual and International Issue}

2. The value of 0.426 with the direction of a positive relationship indicates that if leadership increases by $1 \%$, it will be followed by an increase in the Work Dicipline by 0.426 .

3. The value of 0.146 with the direction of a positive relationship indicates that the value of the supervision has increased by $1 \%$, then it will be followed by an increase in work dicipline of 0.232 .

\section{HYPOTHESIS TESTING}

\section{Partial Test}

1. Based on the partial test results, leadership is significant value is $0.000<0.05$. This shows that there is a significant influence between leadership on the ability to work dicipline.

2. Based on a partial test, the supervision is $2.408>1.984$ and the significant value is $0.006<0.05$. This shows that there is a significant influence supervision on work dicipline.

\section{Simultaneous Test}

Table 9. Simultaneous Test

ANOVA ${ }^{a}$

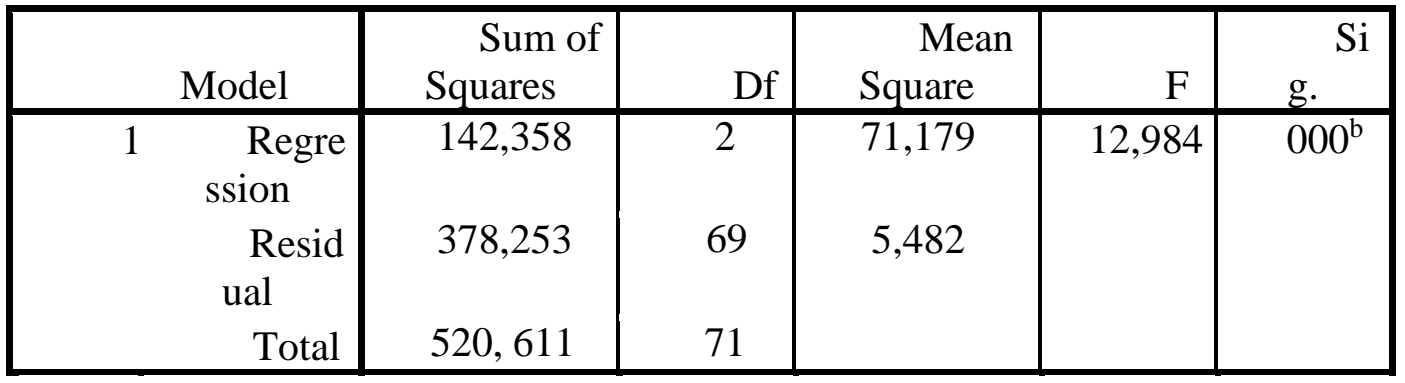

a. Dependent Variable: Work Dicipline

b. Predictors: (Constant), leadership, supervision

Source: Data Processing Results (2021)

From the table above, it can be seen that the value of Fcount is 12,984 > from F table 2,391 and a significant value of $0.000<0.05$, it can be concluded that leadership and supervision jointly affect the ability to work dicipline.

\section{Coefficient of Determination}

Table 10. Coefficient of Determination

Model Summary ${ }^{b}$

\begin{tabular}{|r|c|c|c|c|}
\hline $\begin{array}{r}\mathrm{M} \\
\text { odel }\end{array}$ & $\mathrm{R}$ & $\begin{array}{r}\mathrm{R} \\
\text { Square }\end{array}$ & $\begin{array}{c}\text { Adjusted } \\
\text { R Square }\end{array}$ & $\begin{array}{c}\text { Std. } \\
\text { Error of the } \\
\text { Estimate }\end{array}$ \\
\hline 1 & $523^{\mathrm{a}}$ & 273 & 252 & 2,34135 \\
\hline
\end{tabular}

a. Predictors: (Constant), leadership, supervision

b. Dependent Variable: Work Dicipline

Source: Data Processing Results (2021) 
From the test results above, it can be concluded that the value of $\mathrm{R}$ square is equal to 0.273 or $27.3 \%$. This shows the variation of leadership and supervision in influencing work dicipline of $27,3 \%$, and the remaining $72.7 \%$ is influenced by other variables not examined in this study.

\section{DISCUSSION}

\section{The Effect of Leadership on Employee Discipline}

From the results of the study concluded that there is an influence of leadership on employee work discipline. This can be supported by previous research conducted by Fenny Dwi Oktavia (2014) entitled The Effect of Leadership and Work Discipline on Employee Performance at the Bengkulu City Education Office, the results of this study indicate that leadership has a significant effect on work discipline.

\section{The Effect of Supervision on Employee Discipline}

From the results of the study concluded that there is an effect of supervision on employee work discipline. This can be supported by previous research conducted by Lily Afriza Alni (2016) with the title The Effect of Supervision on Work Discipline of Employees at PT. Arina Multi Karya, the Nestle Division of Medan, which shows that supervision has a significant effect on employee discipline.

\section{The Effect of Leadership and Supervision on Employee Discipline}

From the results of the study concluded that there is an influence of leadership and supervision on employee work discipline. This is in line with Manda Lintang Havany's research (2016) with the title The Effect of Leadership and Supervision on Work Discipline at SPG Pamella Supermarket Yogyakarta Branches One and Three, and has a significant effect. The results of the analysis of this study can be seen that leadership and supervision are very influential by $27.3 \%$ on employee discipline.

\section{CONCLUSION}

From the discussion above, it can be seen that there is an influence of leadership and supervision either partially or simultaneously on employee work discipline.

\section{REFERENCE}

Afandi, A., \& Bahri, S. (2020a). Pengaruh Kepemimpinan, Motivasi Dan Disiplin Kerja Terhadap Kinerja Karyawan. Maneggio: Jurnal Ilmiah Magister Manajemen, 3(2), 235-246.

Afandi, A., \& Bahri, S. (2020b). Pengaruh Kepemimpinan Motivasi dan Disiplin Kerja Terhadap Kinerja Karyawan Asia Muslim Charity Foundation (AMCF) Sumatera Utara. Maneggio: Jurnal Ilmiah Magister Manajemen, 3(2), 235-246.

Arda, M. (2017). Pengaruh Kepuasan Kerja Dan Disiplin Kerja Terhadap Kinerja Karyaawan Pada Bank Rakyat Indonesia Cabang Putri Hijau Medan. Jurnal Ilmiah Manajemen Dan Bisnis, 18(1), 45-60.

Faustyna, F., \& Jumani, J. (2017). Pengaruh Pengembangan Karir Dan Disiplin Kerja Karyawan Pada PT. Pelabuhan Indonesia I (Persero) Medan. Jurnal Ilmiah Manajemen Dan Bisnis, 15(1), 70-78. 
Gede, K., \& Priartini, P. S. (2018). Pengaruh Kepemimpinan Terhadap Kinerja Karyawan Yang Dimoderasi Oleh Motivasi Kerja Pada Bpr Se-Kecamatan Sukawati Gianyar. EJurnal Ekonomi Dan Bisnis Universitas Udayana, 4(7), 2337-3067. https://doi.org/10.24843/eeb.2018.v07.i04.p07

Hasni, P., Noviantoro, D., \& Septiani, D. (2020). Pengaruh Kepemimpinan Terhadap Kinerja Karyawan Pada PT. Win Acces Telecommunicatin Palembang Dengan Kepuasan Kerja Sebagai Variabel Intervening. Jurnal Aplikasi Manajemen \& Bisnis, $1(1), 27-35$.

Jufrizen, J. (2016). Pengaruh Pengawasan Terhadap Kinerja Karyawan Melalui Disiplin Kerja Pada PT. Socfin Indoneesia Medan. Maneggio: Jurnal Ilmiah Manajemen Dan Bisnis, 2(3), 134-147.

Jufrizen, J. (2017a). Efek Moderasi Etika Kerja Pada Pengaruh Kepemimpinan Transformasional Dan Budaya Organisasi Terhadap Kinerja Karyawan. Jurnal Ekonomi Manajemen Dan Bisnis, 18(2), 145-148.

Jufrizen, J. (2017b). Pengaruh Kepemimpinan Dan Budaya Organisasi Terhadap Kinerja Dengan Kepuasan Kerja Sebagai Variabel Intervening. Maneggio: Jurnal Ilmiah Kohesi, 1(1), 166-177.

Kamal, M. B. (2015). Pengaruh Kepemimpinan Dan Pengawasan Terhadap Disilin Kerja Karyawan Pada PT. Perkebunan Nusantara III (Persero). Jurnal Ilmiah Manajemen Dan Bisnis, 15(01), 61-70.

Mockler, R. J. (2006). Management Control Process. Jakarta: Jakarta: PT. Pustaka Binama Pressindo.

Nasution, A. E., \& Lesmana, M. T. (2018). Pengaruh Disiplin Dan Pelatihan Kerja Terhadap Kinerja PT. Hermes Realty Indonesia. Jurnal Manajemen Dan Akuntansi, (August), 115.

Nasution, I. M. (2016). Pengaruh Pengawasan Dan Disiplin Kerja Terhadap Kinerja Karyawan Pada PDAM TIRTANADI Cabang Medan Kota. Jurnal Membangun Ketahanan NasiOnal, 1(1), 20-27.

Nasution, S. N., \& Pasaribu, S. E. (2020). Pengaruh Pengawasan, Motivasi dan Disiplin Terhadap Kinerja Guru pada Yayasan Pendidikan Islam Terpadu Kuntum Bumi Rantauprapat. Maneggio: Jurnal Ilmiah Magister Manajemen, 3(1), 75-91. https://doi.org/10.30596/maneggio.v3i1.4741

Rizal, S. M., \& Radiman, R. (2019a). Pengaruh Motivasi, Pengawasan, dan Kepemimpinan Terhadap Disiplin Kerja Pegawai. Maneggio: Jurnal Ilmiah Magister Manajemen, 2(1), 117-128. https://doi.org/10.30596/maneggio.v2i1.3649

Rizal, S. M., \& Radiman, R. (2019b). Pengaruh Motivasi, Pengawasan Dan Kepemimpinan Terhadap Disiplin Kerja Pegawai. Maneggio: Jurnal Ilmiah Magister Manajemen, 2(1), 117-128.

Sari, N., Lie, D., \& Inrawan, A. (2015). Pengaruh Pengawasan Terhadap Kinerja Pegawai Pada Kantor Pelayanan Kekayaan Negara Dan Lelang Pematang Siantar. Jurnal Maker Manajemen, 1(1), 49-55.

Siagian, T. S., \& Khair, H. (2018). Pengaruh Gaya Kepemimpinan Dan Lingkungan Kerja Terhadap Kinerja Karyawan Dengan Kepuasan Kerja Sebagai Variabel Intervening. Maneggio: Jurnal Ilmiah Magister Manajemen, 1(1), 59-70.

Tanjung, H. (2017). Pengaruh Disiplin Kerja Dan Motivasi Kerja Terhadap Prestasi Kerja Pegawai Pada Dinas Sosial Dan Tenaga Kerja Kota Medan. Jurnal Ilmiah Manajemen 
The Effect of Leadership and Supervision on Employee Discipline at PT. Perkebunan Nusantara III (Persero) Kebun Bandar Selamat

DOI: $10.54443 /$ morfai.v1i2.67

Dan Bisnis, 15(1), 175-182.

Tyas, R. D., \& Sunuharyo, B. S. (2018). Pengaruh Disiplin Kerja Dan Lingkungan Kerja Terhadap Kinerja Karyawan. Jurnal Administrasi Bisnis, 62(1), 172-180. 